\title{
Huzurevinde Yaşayan Yaşlıların Beslenme Durumları ve Günlük Yaşam Aktivitelerinin Belirlenmesi
}

\author{
$\underline{\text { Emine EKİCI }}^{1}$, Merve YETIM COLAK $^{1}$, Ezgi Hasret KOZAN ${ }^{1}$
}

\begin{abstract}
$\ddot{\mathbf{O z}}$
$\mathrm{Bu}$ çalışma huzurevinde yaşayan yaşlıların beslenme durumları ve günlük yaşam aktivitelerinin belirlenmesi amacıyla yapılmıștır. Tanımlayıcı tipte yürütülen araștırmanın evrenini İstanbul Anadolu Yakasında bulunan üç özel huzurevinde yaşayan yaşlılar oluşturmuştur. Evrenin tümü örnekleme alınarak, çalışmaya katılmayı kabul eden bireylerden veri toplanmış, literatüre göre Mini Nutrisyonel Değerlendirme Testinin (MNA) uygulanmayacağı konfüzyon, ileri demansı olan hastalar, kooperasyon kurulamayan hastalar, inme sonrası afazik olan hastalar, akut hastalık durumları (pnömoni), PEG'li hastalar çalışmaya dahil edilmemiştir. Araştırmanın verileri etik kurul onayı ve kurum izni alındıktan sonra Şubat-Mart 2018 tarihleri arasında toplanmıştır. Veriler, 18 sorudan oluşan anket formu, Mini Nutrisyonel Değerlendirme Testi ve KATZ Günlük Yaşam Aktiviteleri Ölçeği (GYA) ile toplanmıştır. Veriler, tanımlayıcı istatistikler, Mann Whitney U, Kruskal Wallis Varyans analizi ve Ki-Kare testi ile değerlendirilmiştir. Yaşlıların yaş ortalaması $78,20 \pm 1,20$, \%58,8'i kadındır. MNA'ya göre yaşlıların \%63'ünün malnütrisyon açısından riskli, \% 9,6'sının malnütrisyon olduğu, \%27,4'ünün ise beslenme sorununun olmadığı bulunmuştur. Kronik hastalık, ana öğünü atlama, çiğneme/yutma güçlüğü ile malnütrisyon riski arasındaki ilişki istatistiksel olarak anlamlı bulunmuştur $(p<0,05)$ Ara öğün sayısı ortalaması ile MNA puan ortalaması arasında istatistiksel olarak anlamlı bir fark tespit edilmiştir $(p<0,05)$. Ara öğün sayısı azaldıkça malnütrisyon riskinin arttı̆̆ı bulunmuştur. GYA'ya göre yaşlıların \%84'ü bağımsız, \%23,3'ü kısmen bağımlı, \% 2,7'si bağımlıdır. Düzenli fiziksel aktivite yapanlarla bağımsız olan yaşlılar arasındaki ilişki istatistiksel olarak anlamlıdır $(p<0,05)$. MNA ile GYA arasındaki ilişkinin istatistiksel olarak anlamlı olduğu bulundu $(p<0,05)$. MNA'ya göre beslenme sorunu olmayan yaşlıların \%95'inin bağımsız olduğu tespit edilmiştir.
\end{abstract}

Anahtar kelimeler: Günlük yaşam aktiviteleri, mini nutrisyonel değerlendirme, malnütrisyon, huzurevi, yaşlı

Yayın Bilgisi

Gönderi Tarihi: 14.12.2018

Kabul Tarihi: 15.01.2019

Online Yayın Tarihi: 31.12.2019

DOI: $10.26453 /$ otjhs.497361

Sorumlu Yazar

Emine EKİCi

Üsküdar Üniversitesi, Sağlık

Bilimleri Fakültesi, Hemşirelik

Bölümü, İstanbul, Türkiye

Tel: 05056462357

E mail: emine.ekici@uskudar.edu.tr

\section{Determination of Nutritional State and Daily Life Activities Elderly Living in Nursing Home}

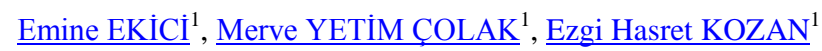

\begin{abstract}
This study was conducted to determine the nutritional status and daily living activities of the elderly living in the nursing home. The population of this descriptive study was composed of elderly living in three different private nursing homes located on the Asian side of Istanbul. Data were collected from the elderly who accepted to participate in the study by taking whole population to the sample, and the, disoriented patients, patients with advanced dementia, patients who could not cooperate, patients with poststroke aphasic syndrome, patients with acute disease (pneumonia), patients with PEG who are not suitable for Mini Nutrient Assessment Test (MNA) application according to the literature were not included in the study. The data of the study were collected between February-March 2018 after the approval of the ethics committee and the permission of the institution. The data were collected with a questionnaire consisting of 18 questions, Mini Nutritional Assessment Test and KATZ Daily Living Activities Scale (GYA). The data were evaluated with descriptive statistics, Mann Whitney U, Kruskal Wallis Variance analysis and Chi-Square test. The average age of the elderly was $78.20 \pm 1,20$ and $58.8 \%$ was female. According to the MNA, $63 \%$ of the elderly were at risk of malnutrition, $9.6 \%$ had malnutrition, and $27.4 \%$ of them did not have nutritional problems. The relationship between chronic disease, skipping a meal, chewing/swallowing difficulty and malnutrition risk were found statistically significant $(p<0,05)$. There was a statistically significant difference between the mean number of snacks and the mean MNA score $(\mathrm{p}<0,05)$. It is found that the malnutrition risk increased as the number of snacks decreased. According to GYA, $84 \%$ of the elderly were independent, $23.3 \%$ were partially dependent and $2.7 \%$ were dependent. The relationship between the regular physical activity and the elderly who are independent is statistically significant $(\mathrm{p}<0,05)$. The relationship between MNA and GYA was found to be statistically significant $(\mathrm{p}<0.05)$. In this study, $95 \%$ of the elderly who do not have a nutritional problem according to MNA, were found to be independent.
\end{abstract}

Keywords: Daily living activities, mini nutritional assessment, malnutrition, nursing home, elderly

${ }^{1}$ Üsküdar Üniversitesi, Sağllk Bilimleri Fakültesi, Hemşirelik Bölümü, İstanbul, Türkiye 


\section{GİRIŞ}

Günümüzde sosyal, ekonomik, tıbbi, bilimsel ve teknolojik gelişmeler sonucunda dünyanın yaşlı nüfusu artmaktadır. 2015 ile 2050 yılları arasında dünyadaki 60 yaş üzeri nüfusun $\% 12$ 'den \%22’ye çıkması beklenmektedir. 2050 y1lında yaşlı insanların \%80 'inin düşük ve orta gelirli ülkelerde yaşayacağı tahmin edilmektedir. Tüm ülkeler bu demografik değişimin getirdiği zorluklarla karşı karşıyadırlar. ${ }^{1,2}$ Yaşlılık döneminde beslenme sorunları ile ilişkili olarak kanser, kalp ve damar hastalıkları, hipertansiyon, diyabet gibi kronik hastalıklarda artış olmaktadır ${ }^{3}$. Bu yaş grubunda dikkat çeken bir başka durum da malnütrisyondur. İşlevsel kapasite ve yeteneklerin kaybı ile yaşlı bireyin günlük yaşam aktiviteleri (GYA) yarı bağımlı ya da tam bağımlı duruma geldiğinden sağlık bakımına olan gereksinmesi de artmaktadır. ${ }^{4}$

Geriatrik yaş grubu; gelişen fizyolojik değişiklikler, kronik hastalıkların ve geriatrik sendromların artması, çoklu ilaç kullanımı gibi nedenlerle özellikli bir yaş grubudur. Yaşlanmanın niteliğini değiştiren çeşitli faktörler arasında beslenmenin önemli bir yeri vardır. Sağlıklı beslenme her yaş grubu için temel bir gereksinimdir. Ancak, yaşın ilerlemesiyle birlikte bireylerin yeme alışkanlıklarında değişimler görülmektedir. ${ }^{3,5}$ Yaşl11ıkta görülen beslenme sorunları yetersiz beslenme ve dengesiz beslenme olarak karşımıza çıkmaktadır. Yaşlılık döneminde dengesiz beslenme sorunları ile ilişkili olarak kanser, kalp ve damar hastalıkları, hipertansiyon, diabetes mellitus, gibi kronik hastalıklarda artış olmaktadır. Yaşlılarda yetersiz beslenme sorunları çoğunlukla protein enerji malnütrisyonu (PEM) olarak görülmektedir. Yetersiz beslenme yaşlanmanın doğal bir bileşeni olmamasına rağmen, yaşlı bireyler fizyolojik, psikolojik ve sosyal risk faktörlerine bağlı olarak malnütrisyon riski altındadırlar. ${ }^{6}$ Malnütrisyonla ilişkili fizyolojik risk faktörleri arasında yetersiz diyet, diş sorunlar1, tat ve koku alma duyusunun azalması, özürlülük durumu ve hareket kısıtlılı̆̆ vb.) bulunur. Sosyal risk faktörleri beslenme bilgi düzeyinde yetersizlik, sosyal izolasyon yalnızlık, yoksulluk, yemek hazırlama kapasitesinin olmamasıdır. Psikolojik risk faktörleri arasında konfüzyon, depresyon, anksiyete ve demans sayılabilir., 5

Yaşlılarda malnütrisyonun en önemli sebebi hastalıklardır. Yaş ilerledikçe akut ve kronik hastalıklar $\operatorname{arttığı~için~yaşlıların~bu~}$ hastalıklardan etkilenmeleri daha çok olmaktadır. Hastalıkların etkisi ile akut ve/veya kronik dönemde besin maddelerine olan ihtiyaç, besinlerin alınımı, tüketimi arasında dengesizlikler ortaya çıkmaktadır. $\mathrm{Bu}$ dengesizlik, bir taraftan yeterli besin maddesinin bulunamamasindan 
kaynaklanabileceği gibi, sunulan gidanın kalitesinin yetersizliği veya gıdanın sunum şekli ile de ortaya çıkabilmektedir.

Diğer taraftan söz konusu dengesizlik, gıdanın yeterli şekilde mevcut olmasına rağmen gıda alımının yetersiz kalmasına da bağlı olabilmektedir. Malnütrisyon ve kronik hastalıklar arasındaki kısır döngü de bu yaş grubu için önemli mortalite ve morbidite nedenidir. ${ }^{8}$ Yaşlı nüfusta, 12 ülkeden toplanan verilerle yapılan geriye dönük bir analizde, malnütrisyonun genel prevalansının yaklaşık \% 23 olduğu bildirilmiştir. En yüksek prevalans rehabilitasyon ortamlarında $(\%$ 50,5), hastanelerde (\% 38,7), bakımevlerinde (\% 13,8) ve toplumda (\% 5,8) görülmüştür. ${ }^{9}$

Türkiye huzurevleri ve bakımevleri nutrisyonel durum değerlendirme projesinde Huzurevleri/bakımevlerindeki yaşlıların $\% 50,2$ 'sinde malnütrisyon veya riskinin olduğu, tarama yapilarak bu durumun kolaylıkla tespit edilebildiği ortaya konmuştur. ${ }^{10}$ Malnütrisyon, yaşlıların günlük yaşam aktivitelerini devam ettirebilmelerinde, kaliteli yaşamalarında önemli bir etkendir. $\mathrm{Bu}$ yüzden her yaşlı hasta mutlaka malnütrisyon açısından değerlendirilmelidir. Malnütrisyonun erken teşhisi, yeterli ve nitelikli tedavisiyle, komplikasyonlar önlenebilmekte, iyileşme hızlanmakta ve yaşlıların fonksiyonelliklerini korumada ve yaşam kalitelerinin kaybolmasını önlemede önemli katkı sağlanabilmektedir. Bu yüzden malnütrisyonun erken tanınması, uygun tedavi edilmesi gereklidir. ${ }^{11}$ Malnütrisyonun erken tanısında, tüm gruplarda beslenme risk taramasının yapılması önem taşımaktadır. Tarama testleri gerçek beslenme düzeyini tespitten daha çok beslenme durumu ile ilişkili özelliklerin, risklerin ve koruyucu faktörlerin erken dönemde tanımlanmasını sağlar. Klinikte yatan hastaların yanı sıra huzurevinde kalan yaşlıların da malnütrisyon açısından beslenme durumları değerlendirilmelidir. ${ }^{8,12}$ Malnütrisyonla mücadelede anahtar konulardan birisi toplumda beslenme durumunun kolay yöntemlerle değerlendirilmesine yönelik sistemler geliştirilmesidir. $^{5}$

Yaşlı bireylerin beslenme durumuna bağlı olarak malnütrisyonlu bireyleri ya da malnütrisyon riski altında olanları belirlemek için çeşitli tarama araçları kullanılmaktadır. 1998-2002 yılları arasında 71 tarama testi geliştirilmiş, bunlardan 21 tanesinin yaşlı bireyler için uygulanabilir olduğu belirlenmiştir. $^{13}$ Ancak zamanla yapılan güvenirlilik ve geçerlilik testleri sonucunda da bunlardan bazılarının diğerlerine göre daha geçerli olduğu rapor edilmiştir. ${ }^{13-15}$ Yaşlı bireylerde beslenme durumunun belirlenmesinde güvenilirliği ve geçerliliği sağlanmış olan ve sıklıkla kullanılan araçlar arasında MNA (Mini Beslenme Değerlendirme Analizi-Mini Nutritional Assessment) önemli bir yer tutmaktadır. 
Ev ortamındaki yaşlıların beslenme durumlarını tanılamak için MNA, Subjektif Global Değerlendirme (SGA) ve Malnütrisyon Üniversal Tarama Aracı

(MUST) karşılaştırılmış, bu üç araç arasında istatistiksel açıdan önemli korelasyonlar bulunmuş, yaşlı bireylerde beslenmeyle ilgili problemler erken dönemde tanılanıp tedavi edilmezse huzurevine yatırılma riskinin, tedavi maliyetlerinin ve mortalite artışının söz konusu olduğu belirtilmiştir. ${ }^{16}$ Araştırmacılar, beslenme durumunun tanılanmasinda MNA'nın diğer araçlara göre daha çok bilindiğini ve en iyi uyumunsa MUST ve SGA arasında bulunduğunu söylemişlerdir. Ev ortamındaki yaşlılarda nütrisyonel durumu tanılamada kullanılmasını uygun gördükleri araç MNA'dır. ${ }^{15}$

Yaşlıların yeterli ve dengeli beslenmelerinin sürdürülmesinde ve beslenme sorunlarının değerlendirilmesinde günlük yaşam aktiviteleri (GYA) de değerlendirilmelidir. Bireylerde fizyolojik, biyolojik ve ruhsal açıdan gerilemelerin görüldüğü yaşlılık dönemi fonksiyonel ve yapısal değişikliklerin yaşandığ1, korunma, gözetim ve bakım gereksinimlerinin arttığı bir dönem olduğu için; günlük yaşam aktivitelerinin yerine getirilmesinde problemler görülmektedir. ${ }^{4,17}$ İşlevsel kapasite ve yeteneklerin kaybı ile yaşlı bireyin günlük yaşam aktiviteleri yarı bağımlı ya da tam bağımlı duruma geldiğinden sağlık bakımına olan gereksinmesi de artmaktadır. ${ }^{4}$
Hemşireler yaşlıların bakım gereksinimlerini planlarken veri toplama aşamasında hem beslenme hem günlük yaşam aktivitelerini değerlendirerek koyduğu hemşirelik tanısına yönelik girişimlerde bulunur. $\mathrm{Bu}$ çalışma huzurevinde yaşayan yaşlıların beslenme durumları ve günlük yaşam aktivitelerinin belirlenmesi amacıyla yapılmıştır.

\section{GEREÇ YÖNTEM}

Tanımlayıcı tipte yürütülen araştırmanın evrenini İstanbul Anadolu yakasında özel işletilen iki huzurevinde yaşayan yaşlı bireyler oluşturdu. Örneklem seçimine gidilmeyip evrenin tamamı örnekleme alınmıştır. Çalışmaya katılmayı kabul eden ve araştırmaya dâhil edilme kriterlerini sağlayan 73 yaşlı birey örneklemi oluşturdu. Literature göre MNA'nın uygulanmayacağı konfüzyon, ileri demansı olanlar, kooperasyon kurulamayan hastalar, inme sonrası afazik olan hastalar, akut hastalık durumu olanlar (pnömoni), PEG'li hastalar çalışmaya dâhil edilmemiştir. $^{12,14}$

Veri Toplama Formları: Araştırmanın verileri kurum izinleri ve 22.01.2018 tarihinde Üsküdar Üniversitesi Girişimsel Olmayan Araştırmalar Etik Kurulundan onay alındıktan sonra Şubat-Mart 2018 tarihleri arasında toplandı. Veriler toplanırken yaşlılardan yazılı ve sözlü onam alındı. Veriler, yaş, cinsiyet, eğitim durumu, huzurevinde kalış süresi, kronik hastalık durumu, düzenli kullanılan ilaç, beslenme alışkanlıklarını (ara, ana ögün 
sayıs1, iştah durumu, çiğneme yutma güçlüğü, diş kaybı, su tüketimi) sorgulayan 18 sorudan oluşan anket formu, Mini Nutrisyonel Değerlendirme Testi (MNA) ve KATZ Günlük Yaşam Aktiviteleri Ölçeği (GYA) ile toplandı.

Mini Nutrisyonel Değerlendirme Testi (MNA): MNA, beslenme durumunun değerlendirilmesinde hılı ve güvenilir bir yöntemdir. MNA'nın geçerliliği ve güvenilirliliği 1994 yılında Guigoz ve arkadaşları tarafindan yapılmıştır ${ }^{18}$. MNA'nın Türkiye'de geçerlilik çalışması Sarıkaya tarafından 2013 yılında yapılmış, yaşlıların taranmasında geçerli bir yöntem olduğu ortaya konmuştur MNA 4 bölümden oluşmakta ve 18 öğe içermektedir ${ }^{19}$. Bu dört bölümü; antropometrik değerlendirme (BKİ, kilo, kol ve baldır çevreleri); genel değerlendirme (hayat tarz1, ilaç, mobilite, depresyon ve demans belirtileri); kisa beslenme değerlendirmesi (öğün sayısı, gida ve sıv1 alımı, beslenmede özerklik) ve subjektif değerlendirme (sağlık ve beslenme konusunda benlik alg1sı) oluşturur. Testten en düşük 0 , en yüksek 30 puan alınmaktadır. Testten 23 puan ve üzerinde alanların beslenme durumunun yeterli olduğu; 17 ve 23,5 puan arasında alanların malnutrisyon riski altında olduğu ve 17 puanın altında alanlar malnutrisyonlu olarak değerlendirilmektedir.

KATZ Günlük Yaşam Aktiviteleri Ölçeği (GYA) : GYA, Katz ve arkadaşları tarafından 1970'de geliştirilmiştir ${ }^{20}$. Ölçeğin Türkçe'ye uyarlaması, geçerlik ve güvenirliği Diker ve arkadaşları tarafından 2001 yılında yapılmıştır. ${ }^{21}$ GYA, bireylerin günlük yaşam aktivitelerindeki (banyo yapma, giyinme, tuvalet ihtiyac1 transfer, kontinans, beslenme), bağımlılık durumlarını değerlendirmektedir. Etkinlikler "Bağımlı", "Kısmen bağımlı" ve "Bağımsız" olmak üzere üç düzeyde ölçülmektedir. GYA ölçeğinden alınan puanların değerlendirilmesinde; 0-6 puan arasında olanlar bağımlı; 7-12 puan arasında olanlar kısmen bağımlı, 13-18 puan arasında olanlar bağımsız olarak değerlendirilmektedir. Veriler, üç özel huzurevinde araştırmacılar tarafından anketlerin yüz yüze görüşme ile doldurulmasıyla elde edildi. Veri toplamada kalibrasyonu sağlanmış tartı ve boy ölçerden oluşan bir antropometri kiti kullanıldı. Antropometrik ölçümler ayakkabıları olmadan ve hafif kıyafetler giydikleri özel bir ortamda (hemşire odas1, revir vb) topland1.

Kapsamlı beslenme değerlendirmesinde antropometik ölçümler (kilo, boy, orta-kol ve baldır çevreleri) mezura ve baskül kullanılarak yapıldı. Bağımlı değişken olarak yaşlıların malnütrisyon durumları, bağımsız değişkenler ise günlük yaşam aktiviteleri düzeyi, sosyo demografik özellikler ile beslenme alışkanlıklarını sorgulayan tanıtıcı özellikler olarak belirlendi.

İstatistiksel Analizler: Veriler bilgisayar ortaminda SPSS paket programının 22.0 sürümüne aktarılmış, parametrik ve non- 
parametrik istatistik analizleri ile değerlendirilmiştir. Tanımlayıcı veriler sayı, yüzde ve ortalama ile gösterilmiştir. Ölçek puanları ile bağımsız değişkenler arasındaki ilişki parametrik varsayımları yerine getiren verilerde Varyans analizi (ANOVA) ve t Testi ile parametrik varsayımları yerine getirmeyen verilerde ise Kruskal Wallis Varyans analizi, Mann-Whitney U testi ile değerlendirilmiştir. Sayımla belirtilen veriler Ki-Kare testi ile değerlendirilmiştir. Elde edilen bulguların anlamlılık seviyesi, güven aralığ $\% 95$ $(p<0,05)$ kabul edilerek belirlenmiştir.

Araştırmanın Değişkenleri: Araştırmanın bağımlı değişkenleri Mini Nutrisyonel Değerlendirme (MNA) toplam puanı ve Günlük Yaşam Aktiviteleri Ölçeği Toplam Puanı; bağımsız değişkenleri ise sosyodemografik özellikler ve beslenme alışkanlıklarıdır.

\section{BULGULAR}

Huzurevinde yaşayan yaşlıların, \%58,9'unun kadın, \% 41,1'inin erkek, yaş ortalamasının

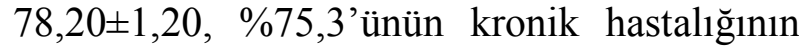
bulunduğu belirlendi. Yaşl1ların \%91,8'inin günde 3 ana ögün yediği, \%23,3'ünün hiç ara öğün yapmadığı， \%11'inin iştahının kötü olduğu, \%27,4'ünün çiğneme/yutma güçlüğü olduğu saptanmıştır. Yaşl1ların \%69,9'unun hastalığı için özel diyet uyguladığı, \%75,3'ünün düzenli ilaç kullandığg, $\% 15,1$ 'inin sigara içtiği bulundu.
MNA'ya Göre Yaşlıların Beslenme Durumları:

Yaşliların MNA' ya göre \%63'ünün malnütrisyon riski olduğu ve \% 9,6'sının malnütrisyonlu olduğu bulundu (Tablo 1).

Kronik hastalı̆̆ı olanların \%69,1'inin MNA'ya göre malnütrisyon riski olduğu saptanmıştır. Kronik hastalık ile malnütrisyon riski arasındaki ilişki istatistiksel olarak anlamlıdir $\quad(\mathrm{p}<0,05) . \quad$ Diyabeti olan katılımcıların \%46,7'sinin malnütrisyon riski olduğu saptanmıştır. Diyabet ile malnütrisyon riski arasında istatistiksel olarak anlamlı fark $\operatorname{vardir}(\mathrm{p}<0,05)$.

Ana öğünü atlayanların \%91,7'sinin malnütrisyon açısından riskli grupta olduğu, ana öğünü atlama ile malnütrisyon riski arasında istatistiksel olarak anlamlı fark tespit edilmiştir $(p<0,05)$. Çiğneme/yutma güçlüğü olanların \%85'i malnütrisyon açısından riskli gruptadır. Çiğneme yutma güçlügü ile malnütrisyon riski arasındaki fark istatistiksel olarak anlamlıdır $(p<0,05)$. Günde alınan ara öğün sayı ortalaması beslenme sorunu olmayanlarda 1,55 malnütrisyon riski olanlarda 1,15 , malnütrisyonlu olanlarda 0,71 olarak bulunmuştur. Ara öğün sayısı ortalamas1 ile MNA puan ortalaması arasinda istatistiksel olarak anlamlı fark tespit edilmiştir $(p<0,05) \quad$ Ara öğün sayısı azaldıkça malnutrisyon riskinin arttığı bulundu (Tablo 2). 
Günlük Yaşam Aktivitelerine İlişkin

\section{Bulgular}

Yaşlıların Katz Günlük Yaşam Aktiviteleri Ölçeğine göre \%23,3’ünün kısmen bağımlı, \% 2,7'sinin bağımlı olduğu görüldü (Tablo 3).

MNA'ya göre beslenme sorunu olmayanların \%95'inin GYA'ne göre bağımsız grupta olduğu tespit edilmiştir. MNA ile GYA arasındaki ilişki istatistiksel olarak anlamlıdır $(\mathrm{p}<0,05)($ Tablo 4).

\section{TARTIŞMA}

Çalışmamızda huzurevinde yaşayan yaşlıların MNA'ya göre büyük çoğunluğunun (\% $\%$ 63) malnütrisyon açısından riskli grupta olduğu bulunmuştur. İstanbul'da büyük çaplı bir huzurevinde 2009-2010 yılında yapilan kesitsel çalışmada malnütrisyon riski \%22,8; Akademik Geriatri Derneği tarafından yapılan Türkiye Huzurevleri ve Bakımevleri Nutrisyonel Durum Değerlendirme Projesinde ise malnütrisyon riski $\% 38$ olarak bulunmuştur. $^{8,22}$ Aile ve Sosyal Politikalar Bakanlığına bağlı huzurevlerinde rastgele örneklemle seçilen huzurevlerinde 330 yaşlıyla yapılan çalışmada malnütrisyon riski $\% 35,1$, malnütrisyon sıklığı $\% 15,5$ bulunmuştur. ${ }^{23} \mathrm{Bu}$ çalışmada yaşlılardaki malnütrisyon riski diğer çalışmalara göre yüksek bulunmuştur. $\mathrm{Bu}$ durumun örneklem sayısının az olmasından kaynaklandığı düşünülmektedir. Bu çalışmada çiğneme/yutma güçlüğü yaşayan yaşl1ların \%85'inin MNA'ya göre malnütrisyon açısından riskli grupta olduğu görüldü $(p<0,05)$. Belçika'da 2329 yaşlı hasta ile gerçekleştirilen çalışmada bizim çalışma bulgularına benzer olarak yutma güçlügü yaşayan hastaların \%71'inde malnutrisyon saptanmıștır. $^{24} \mathrm{Bu}$ sonuç çiğneme ve yutma güçlüğü olan hastaların malnütrisyon ve beslenme sorunları açısından sık izlenmesi gerektiğini düşündürmektedir.

$\mathrm{Bu}$ çalışmada kronik hastalığı olanların \%69,1'inin MNA' ya göre malnütrisyon açısından riskli grupta olduğu bulundu $(p<0,05)$. Bizim çalışma bulgumuzdan farklı olarak yapılan başka bir çalışmada kronik hastalık ile MNA arasinda anlamlı fark bulunmamıştır. $^{25}$ Altunok ve ark.'a göre ise yaşlilarda malnütrisyonun en s1k nedeni gelişmiş ülkelerde kronik hastalık varlığı, gelişmekte olan ülkelerde ise beslenme durumunun yetersiz olmasıdır. ${ }^{26}$

Çalışmamızda ara öğün sayısı azaldıkça malnütrisyon riskinin arttığı bulunmuştur $(\mathrm{p}<0,05)$. Bizim çalışma bulgumuza benzer olarak Adıgüzel ve Acar Tek'in 2016 yılında yaptığı çalışmada ara öğün tüketim sayıları ile MNA arasında negatif ilişki bulunmuştur. Malnütrisyon açısından ara öğün alımının izleminin önemli olduğu sonucuna varılmıştır. $^{27}$

Bu çalışmada MNA' ya göre beslenme sorunu olmayan yaşlıların \%95'inin bağımsız olduğu görüldü $(p<0,05)$. Bizim araştırma bulgumuza benzer olarak Erdoğan ve ark. tarafindan dahiliye kliniğe başvuran bireyler ile yapılan 
çalışmada da beslenme bozukluğu olmayan grubun günlük yaşam aktivitelerinde bağımsız oldukları bulunmuştur. ${ }^{28}$ Yapılan başka bir çalışmada da demanslı yaşlı bireylerin MNA ile günlük yaşam aktiviteleri arasında güçlü ve pozitif bir ilişki olduğunu bulunmuştur. ${ }^{29} \mathrm{Bu}$ sonuçlar yaşlının fonksiyonel durumunun malnütrisyon durumunu etkileyebileceğini düşündürmektedir. Bağımlı durumdaki yaşlıların malnütrisyon açısından sık izlenmesi gerekmektedir.

\section{Sonuç}

$\mathrm{Bu}$ çalışma yaşlılarda görülen malnütrisyonun huzurevlerinde önemli bir sorun olarak dikkate alınması gerektiğini bir kez daha ortaya koymuştur. Huzurevinde yaşayan yaşlı bireylerin malnütrisyon ve malnütrisyon riski oranı yüksektir. Kronik hastalık, ana ögünü atlama, ara ögün sayısı ve çiğneme/yutma güçlüğü olması bu çalışmada da malnutrisyonu etkileyen bir durum olarak karşımıza çıkmıştır. MNA' ya göre beslenme sorunu olmayanların \%95'inin GYA'ya göre bağımsı grupta olduğu görülmektedir.

\section{Öneriler}

- Yaşlilarda malnütrisyon oluşmadan önce koruyucu yaklaşımın benimsenerek erken dönemde risk faktörlerinin belirlenmesi ve malnütrisyon riskini belirlemek için MNA’nın kullanımı önerilmektedir.

- Fonksiyonel kapasitede kısmen bağımlı ve bağımlı yaşlıların malnütrisyon riski yüksek olduğundan beslenme durumlarının sık aralıklarla izlenmesi ve değerlendirilmesi gerekmektedir.

- Hemşireler yaşlı bireylerin nutrisyonel durumunun değerlendirirken fonksiyonel durumlarını ayrıca malnütrisyon için risk faktörleri içinde yer alan çiğneme yutma güçlüğü, kognitif durum, depresyon, oral problemler, alınan ilaç sayısı, gıda alımında düşüş, atlanmış öğünler gibi parametreleri de dikkate almalıdırlar.

\section{KAYNAKLAR}

1. WHO. Global health and aging. http://www.who.int/ageing/publications/glo bal_health.pdf. 2010. Erişim Tarihi: 2.06.2018.

2. WHO. Aging and health http://www.who.int/newsroom/factsheeds/d etails/aging and health. 2018. Erişim tarihi: 2.06.2018.

3. Baz S, Ardahan M. Yaşlılarda malnütrisyon ve hemşirelik yaklaşımları. Balikesir Sağlik Bil Derg. 2016;5(3):148-153.

4. İnanır İ, Kayış A, Yılmaz K. Yaşlı hastaların günlük yaşam aktiviteleri. Akad Geriatri. 2013;5(1):64-72.

5. Aslan D, Şengelen M, Bilir N. Yaşl1lık döneminde beslenme sorunları ve yaklaşımlar. Geriatri Derneği Eğitim Serisi 1, Öncü Basımevi, Ankara; 2008.

6. Huhman M B, Perez, V, ve ark. A SelfCompleted nutrition screening tool for community- dwelling older adults with high 
reliability: A compparıson study. J Nutr Health Aging. 2013;17(4):339-343.

7. Kansal D, Baliga S S, Kruthika K, Mallapur MD. Nutritional assessment among elderly population of rural Belagavi: a crosssectional study. Int $\mathrm{J}$ Med Sci Public Health. 2016;5:1496-1499.

8. Arıoğul S. Yaşlilarda malnütrisyon k1lavuzu. In: Malnütrisyonun önemi. Akademik Geriatri Derneği Yayını. 2013:126.

9. Kaiser M J, Bauer J M, Rämsch C. ve ark. Frequency of malnutrition in older adults: a multinational perspective using the mini nutritional assessment. J Am Geriatr Soc. 2010;58(9):1734-1738.

Doi:

10.1111/j.1532-5415.2010.03016.

10. Cankurtaran M, Saka B, Sevnaz S ve ark. Türkiye huzurevleri ve bakımevleri nutrisyonel degerlendirme projesi. http://www.akademikgeriatri.org/files/Akad emik_Geriatri_2012/geriatriKitap2012.pdf 2012. Erişim Tarihi: 02.06.2018.

11. Saeidlou S N, Nouri K, Merdol T, Mikaili P, Bektaş Y. Assessment of the nutritional status and affecting factors of elderly people living at six nursing homes in Urmia, Iran. J Academic Research. 2011;3(1):173-181.

12. Delegge M. Evrensel Malnütrisyon Tarama Yöntemi. Çev. Ed. Malazgirt Z, Topgül K. In:Nütrisyon ve Gastrointestinal Hastalı. Nobel
Matbaacilık. İstanbul. Nobel Tip Kitapevleri; 2011.

13. Green S M, Watson R. Nutritional screening and assessment tools for older adults: literature review. J Advance Nursing. 2006;54(4):477-490.

14. Ülger Z, Halil M, Kalan I, ve ark. Comprehensive assessment of malnütrition risk and related factors in a large group of community-dwelling older adults. Clin Nutr. 2010;29(4):507-511.

15. Phillips M B, Folley A L, Bernard R, Isenring $\mathrm{E} A$, Miller $\mathrm{M}$ D. Nutritional screening in community-dwelling older adults: a systematic literature review. Asia Pacific Journal of Clin Nutr. 2010;19(3):440-449.

16. Kozakova R, Zelenikova R. Assessing the Nutritional Status of the Elderly Living at Home. European Geriatric Medicine. 2014;5(6):377-381.

17. Berberoğlu U, Gül H, Eskiocak M, ve ark. Edirne Huzurevi'nde kalan yaşlıların kimi sosyo-demografik özellikleri ve Katz İndeksine göre günlük yaşam etkinlikleri. Turkish Journal of Geriatrics. 2002;5(4):144-149.

18. Vellas B, Guigoz Y, Philip J, ve ark. Mini NutritionalAssessment: a practical assessment tool for grading the nutritional status of elderly patients. Nutrition. 1999;15(2):116-122. 
19. Sarıkaya D. Geriatrik hastalarda Mini Nutrisyonel Değerlendirme (MNA) testinin uzun ve kisa (MNA-SF) formunun geçerlilik çalışması, Hacettepe Tıp Fakültesi İç hastalıkları Anabilim Dalı Uzmanlık Tezi .2013

20. Katz S, Down T D, Cash H R, Grotz R C. Progress in the development of the index of ADL. The Gerontologist. 1970;10(1):20-3.

21. Diker J, Etiler N, Yıldız M, Şeref B Altmış beş yaş ve üzerindeki kişilerde bilişsel durumun günlük yaşam aktiviteleri, yaşam kalitesi ve demografik değişkenlerle ilişkisi: Bir alan çalışması. Anadolu Psikiyatri Dergisi. 2001;2(2):79- 86.

22. Saka B. Yaşlı hastalarda malnütrisyon. Klinik Gelişim Dergisi.2012; 25:3, 82-89.

23. Başıbüyük G Ö ve ark. Huzurevinde kalan yaşlılarda malnütrisyon sıklığı. Ahi Evran Üniversitesi Sosyal Bilimler Enstitüsü Dergisi. 2017;3(2):339-348

24. Vanderwee K, Clays E, Bocquaert I, Gobert M, Folens B, Defloor T. Malnutrition and associated factors in elderly hospital patients: A Belgian crosssectional, multi-centre study. Clin Nutr. 2010; 29(4):469-476.

25. Akan H, Ayraler A, Hayran O. Evde sağlık birimine başvuran yaşlı hastaların beslenme durumları. Türk Aile Hek Derg. 2013;17(3):106-112.

26. Altunok H, Atalay B. I, Önsüz M.F, Işıklı B. Yaşlılık döneminde önerilen tarama testleri. TAF Preventive Medicine Bulletin. 2016;15(6):588-595.

27. Adıgüzel E. Evde Bakım Hizmeti Alan Bireylerde Beslenme Durumunun ve Yaşam Kalitesinin Değerlendirilmesi Ve Evde Bakım Hizmetleri Kapsamında Diyetisyenin Rolü. Danışman: Doç. Dr. Nilüfer ACAR TEK. Gazi Üniversitesi, Sağlık Bilimleri Enstitüsü. Yüksek Lisans Tezi, Ankara, 2016.

28. Erdoğan T, Tunca H. Dahiliye kliniğine başvuran geriatrik hastaların çok yönlü fonksiyonel değerlendirilmesi ve beslenme durumlarının irdelenmesi. Osmangazi Tıp Dergisi. 2016;38(3):1724.

29. Rullier L, Lagarde A, Bousson J, Bergua V, Gateau PB. Nutritional Status of Community-DwellingOlder People with Dementia: Associations with individual and Family Caregivers' Characteristics. Int J Geriatric Psychiatry. 2013;28(6):580588. 
Tablo 1. Mini Nutrisyonel Değerlendirme Testi’ne Göre Yaşlıların Beslenme Durumları.

\begin{tabular}{lll}
\hline MNA * & n & \% \\
\hline Beslenme sorunu yok & 20 & 27,4 \\
Malnütrisyon riski var & 46 & 63,0 \\
Malnütrisyonlu & 7 & 9,6 \\
Toplam & 73 & 100 \\
\hline
\end{tabular}

* Mini Nutrisyonel Değerlendirme Testi 
Tablo 2. Yaşlı Bireylerin Bazı Tanıtıcı Özellikleri İle Mini Nutrisyonel Değerlendirme Testi Sonuçlarının Karşılaştırılması.

\begin{tabular}{|c|c|c|c|c|c|c|c|c|c|}
\hline \multirow[t]{3}{*}{ Değiş̧kenler } & & \multicolumn{8}{|c|}{$*$ MNA (n=73) } \\
\hline & & \multicolumn{2}{|c|}{ Beslenme Sorunu Yok } & \multicolumn{2}{|c|}{ Malnutrisyon Riski } & \multicolumn{2}{|c|}{ Malnutrisyonlu } & \multirow[t]{2}{*}{$* * x^{2}$} & \multirow[t]{2}{*}{$\mathbf{p}$} \\
\hline & & $\mathbf{n}$ & $\%$ & $\mathbf{n}$ & $\%$ & $\mathbf{n}$ & $\%$ & & \\
\hline \multirow[t]{3}{*}{ Kronik Hastalık } & Var & 11 & 20 & 38 & 69,1 & 6 & 10,9 & \multirow{2}{*}{6,168} & \multirow[b]{2}{*}{0,046} \\
\hline & Yok & 9 & 50 & 8 & 44,4 & 1 & 5,6 & & \\
\hline & Atlamayan & 19 & 39,6 & 24 & 50,0 & 5 & 10,4 & \multirow{3}{*}{11,651} & \\
\hline \multirow{2}{*}{$\begin{array}{l}\text { Ana Öğ̈̈n } \\
\text { Atlama }\end{array}$} & Atlayan & - & - & 11 & 91,7 & 1 & 8,3 & & \multirow[t]{2}{*}{0,020} \\
\hline & Bazen & 1 & 7,7 & 11 & 84,6 & 1 & 7,7 & & \\
\hline \multirow{2}{*}{$\begin{array}{l}\text { Çiğneme/Yutma } \\
\text { Güçlüğğü }\end{array}$} & Yok & 20 & 37,7 & 29 & 54,7 & 4 & 7,5 & \multirow{2}{*}{10,502} & \multirow{2}{*}{0,005} \\
\hline & Var & - & - & 17 & 85 & 3 & 15 & & \\
\hline
\end{tabular}

*Mini Nutrisyonel Değerlendirme Testi; ${ }^{* *}$ x2: ki-kare testi 
Tablo 3. Günlük Yaşam Aktiviteleri Ölçeği’ne Göre Yaşlıların Bağımlılık Düzeyleri.

\begin{tabular}{lll}
\hline GYA* & n & \% \\
\hline Bağımlı & 2 & 2,7 \\
Kısmen Bă̆ımlı & 17 & 23,3 \\
Bağımsız & 54 & 74 \\
Toplam & 73 & 100 \\
\hline
\end{tabular}

* Günlük Yaşam Aktiviteleri Ölçeği 
Tablo 4. Günlük Yaşam Aktiviteleri Ölçeği’ne Göre Bağımlılık Düzeyleri İle Beslenme Durumlarının Karşılaştııılması.

$$
\text { GYA* }(n=73)
$$

\begin{tabular}{|c|c|c|c|c|c|c|c|c|c|c|c|}
\hline \multirow{4}{*}{ MNA** } & & \multicolumn{2}{|c|}{ Bağımlı } & \multicolumn{2}{|l|}{$\begin{array}{l}\text { Kısmen } \\
\text { Bağımlı }\end{array}$} & \multicolumn{2}{|c|}{ Bağımsız } & \multicolumn{2}{|c|}{ Toplam } & \multirow{2}{*}{$* * * \mathbf{x}^{2}$} & \multirow{2}{*}{$\mathbf{p}$} \\
\hline & & $\mathbf{n}$ & $\%$ & $\mathbf{n}$ & $\%$ & $\mathbf{n}$ & $\%$ & $\mathbf{n}$ & $\%$ & & \\
\hline & Beslenme Sorunu Yok & - & - & 1 & 5 & 19 & 95 & 20 & 100 & & \\
\hline & $\begin{array}{l}\text { Malnutrisyon Riski } \\
\text { Var }\end{array}$ & 1 & 2,2 & 12 & 26,1 & 33 & 71,7 & 46 & 100 & & \\
\hline
\end{tabular}

Malnutrisyonlu

$\begin{array}{llllllll}1 & 14,3 & 4 & 51,7 & 2 & 28,6 & 7 & 100\end{array}$

13,657

* Günlük Yașam Aktiviteleri Ölçeği; **Mini Nutrisyonel Değerlendirme Testi; ${ }^{* * *}$ x2: ki-kare testi 